\title{
An Analysis of the Narrative Function of the Economic Elements in Their Eyes Were Watching God
}

\author{
Liu Jiana ${ }^{1}$ \\ ${ }^{1}$ Department of Foreign Language, Xinhua College of Sun Yat-Sen University, Guangzhou, Guangdong Province, China.
}

\begin{abstract}
In Zora Neale Hurston's representative work, Their Eyes Were Watching God, economic elements occupy a large proportion. This paper aims to analyze economic elements and explore the narrative function of the economic elements in the novel: to participate in the construction of the social background, to advance the development of the plot and create the conflict between characters, to promote the shaping of the characters. Through the narrative function of economic elements in the above aspects, Hurston explores and reflects on the economic status of black women, the value of black women's life, and the equal status of black men and women in society.
\end{abstract}

\section{Introduction}

Zora Neale Hurston is regarded as one of the most outstanding writers in the Harlem Renaissance[1], and her masterpiece Their Eyes Were Watching God is not only recognized as a classic of black literature, but also a classic of feminist literature and a classic of 20th century American literature[2]. Many scholars at home and abroad have studied this novel from the perspectives of women, race, culture and narrative, but the economic elements, which occupy a large proportion in the story, have not received due attention. Dr. Lv Qi, a domestic scholar, analyzed the capital logic in this novel with Bourdieu's capital theory[3]; Dr. Hu Xiaojun analyzed the economic status of black women through this novel[4]; Foreign scholar Abigail Manzella analyzed the displacement of economy and environment in the migration of the novel [5]; Thomas Haddox used George Bataille's concept of consumption to explain the various conflicts in the novel [6]. In addition to the above scholars, few scholars have systematically analyzed the economic elements in Their Eyes Were Watching God. In fact, the economic element is not only an indispensable part of the novel, but also runs through the whole work and assumes the narrative function. The story of the protagonist, Janie Crawford, is told by herself to her friend Pheoby, and her very first statement is about money: "They don't need to worry about me and my overhalls long as Ah still got nine hundred dollars in de bank."'7] A good economic position gives Janie the confidence, but also foreshadows the importance of the economic element in this story. This paper will explore the narrative function of economic elements in this novel through the economic elements in
Their Eyes Were Watching God: how the economic elements construct the social background of the story, how they promote the development of the plot as well as the creation of conflicts, and how they shape the image of the characters. In addition, Hurston's exploration of black economic status of women, her thought of their life value and her pursuit and confusion of the equal status of black men and women are shown through the functions of economic factors mentioned above.

\section{Social Background Constructed by Economic Elements}

Their Eyes Were Watching God was published in 1937, which is during the Great Depression (1929-1939), one of the worst recessions in modern history. Black women were particularly vulnerable at that time, whether they worked as blue collar workers or white collar workers. They were less likely to benefit from unions or New Deal, therefore they were marginalized[8]. Black women in this period, whether engaged in industry or agriculture, were in a very miserable situation. They were under the triple burden of male prejudice, white irrational hatred and lack of black power[9], therefore bear heavy economic pressure. Although the novel does not directly reflect the specific time of the story, Hurston is clearly aware of the burden of black women. The description of the burden borne by black women in the novel is very similar to the difficult situation of black women during the Great Depression, as Janie's grandmother said to her: "white man throw down de load and tell de nigger man tuh pick it up. He pick it up because he have to, but he don't tote it. He hand it to his womenfolks." The special creative background offers the economic elements in the novel a

hopefu10606@163.com 
profound connotation. In the novel, the economic elements construct two distinct social backgrounds in three zones. Janie has lived in three places successively, namely, West Florida, which is her hometown, the newly established town for blacks named Eatonville and the Everglades, a place far away from the city and prosperity. The first two areas are towns with institutions, built on a realistic economic base, and the third area, the Everglades, is a place where everything grows savagely. Janie's life in the Everglades is based on a very unrealistic economic structure. The social background of West Florida and Eatonville is similar. People have reverences for good economic status and black women have to rely on men who are more economically and socially dominant, and therefore under the double oppression of race and male power. In West Florida, Janie obeyed her mother and married Logan Killicks, a wealthy black man. Even though Jenny felt depressed and bored by the loveless marriage with Logan, her Nanny still comforted her by telling her that: "Heah you is wid de onliest organ in town, amongst colored folks, in yo' parlor. Got a house brought and paid for and sixty acres uh land right on de big road ...", and tried to persuade Janie to fill the spiritual emptiness with material wealth. Nanny idea represented the majority of people's idea in her hometown, and Janie, with financial resources provided by her husband, was respected by people-- "verybody got tuh tip dey hat tuh to you and call you Mis' Killicks". In West Florida, marriage, economic status and men seem to reach a secret conspiracy, which deeply hurt Janie's vision of love and her self-esteem, therefore, after a fight with Logan, Janie and Joe Starks eloped to the a small town being established-Eatonville. The original Eatonville was only made up of a dozen small houses, but with the development of Joe's store and Joe being elected mayor of Eatonville, the town gradually grew larger and more prosperous. Joe's social status changed, so did the attitude of the people around him, and Joe revealed his desire to control and dominate Janie. They consider her as a part of authority as she "slept with authority" while Joe holds that he was just pouring honor all over her. In the society of Eatonville, Janie lost the right to her freedom and even her voice, and became an attachment of Joe, living unconsciously and numbly for many years. After Joe died, she met a man named Vergible Woods, nicknamed Tea Cake, and moved to the Everglades with him.

Wang Jiaxiang, the translator of Their Eyes Were Watching God, believes that Janie's third stage of life is based on an unrealistic economic structure. He holds that this reflects Hurston's realistic attitude, indicating that she did not believe that under the social and economic conditions at that time, men and women could establish truly equal relations and women could gain full rights as human beings.[10] The Everglades was completely different from West Florida and Eatonville. In the Everglades, a fertile land where people were wild, they worked, shot, argued, played cards, and lived hard but happily. It is not an ideal utopia, and the people who come here to seek to survive are "evil because of ignorance, falling apart because of poverty" but ironically, it is in this wild society of the Everglades that Janie gains the equality and respect what she does not have a chance to enjoy in West Florida and Eatonville. In the Everglades, an unrealistic society, men and women get the same working opportunities. Janie is no longer restricted by domestic affairs and social resources, and participate in social life and production.

Domestic labour of women has lost its meaning in comparison with labour of men for the means of subsistence-- labour of men is everything, while labour of women is an insignificant adjunct [11]. Janie, who has got rid of the shackles of domestic labor, has the same productivity as men, and to a certain extent, she has got rid of the fate of becoming an accessory. Hurston, with her keen eyes, captures the most important aspect of black women's life: their economic status, and reveals the most substantial problem in their economic life: gender division of labor is the most fundamental reason for black women's economic subordination. The tragic part is that in real society (such as West Florida and Eatonville) at that time, black women could not get rid of gender division of labor and differential treatment. Hurston creates the special social space of the Everglades and constructs a society based on an unrealistic economic structure, which can be seen as her attempt to find a solution to the oppression of black women in her works, that is, a society in which black men and black women have equal job opportunities and economic status.

\section{Plot and Conflicts Promoted by Economic Elements}

The history of human marriage tells us that whether the ownership of means of production takes the form of public ownership or private ownership, whether men and women possess the means of production equally or whether men possess the ownership of means of production singly, constitute the essence of marital economic relations. [12] Just as the plot of Their Eyes Were Watching God revolves around Janie's three marriages, the economic elements that account for a large proportion of all three marriages. The possession of the means of production, superficially promotes the development of the plot: In the first marriage, for the purpose of not letting Janie suffer from poverty, Grandma married Jenny to Logan, who had good assets, but Jenny could not bear this loveless and depressed marriage and eloped with Joe; In the second marriage, Janie depended on the material wealth created by Joe, who oppressed her in many ways and trapped her to domestic affairs after he became the mayor of Eatonville with his outstanding leadership and economic strength, which forced Janie to resist; In the third marriage, with the inheritance of the dead Joe's property, Janie married a penniless man who truly loved her and moved to the Everglades to work and live, and finally Tea Cake died in an accident. In the first marriage, the conflicts between Janie and Logan are that she doesn't love him, and that she does not give in to him because of his property, but Logan wants Janie to feel that she is inferior to him and controlled by him; The conflicts in the second marriage are similar to that in the first one in that Joe uses 
his economic and social status to force Janie to submit to him, but Janie is brave enough to tear Joe's hypocritical mask, break his illusion of male attraction and leave him depressed to death; In the third marriage, Janie becomes the property owner, and her two major conflicts with the penniless Tea Cake-- the suspicion that he approached her for money and the suspicion that he took her money and left without saying goodbye-- are also relevant to financial problems.

However, under the superficial plot promoted by economic elements, there is Covert Processions-- If we break the shackles of long-term criticism tradition, while paying attention to the development of the plot, we should expand our eyes to another narrative movement behind it, that is, the narrative undercurrents I call Covert Processions[13]. The narrative undercurrents driven by economic elements in Their Eyes Were Watching God does not only lie in the conflicts among Janie and others, but mainly in the conflicts between Janie and herself. The irreconcilable conflict between Janie and herself in the first and second marriages is that she does not realize that the two marriages start with a wrong reliance, that is, to depend on the material wealth created by men, and therefore cannot bring her a desired freedom and equality. Janie was a naive young lady in her first marriage, and she agreed to marry Logan largely because she was convinced by Nanny's story about the suffering of black women. She complained to her mother: "Ah ain't takin' dat ole land tuh heart neither. Ah could throw ten acres of it over der fence every day and never look back to see where it fell. Ah feel de same way 'bout Mr. Killicks too.” At that time, Jenny said she didn't care about Logan's property but she still depended on his wealth in real life. The contradiction of only knowing what she didn't want and not knowing what she wanted confined her. Finally, she met Joe, who had three hundred in his pocket and could bring freshness to her life.

Still unaware of her dependence after meeting Joe, Janie continued to rely on men and their supplies. Just when she decided to run away with Joe, they were still talking about "when he could be a big ruler of things and with her reaping the benefits". When Joe first met Janie he used two "ain't got no" in succession to emphasize that Janie shouldn't be working, and then he said, "a pretty doll-baby lak you is made to sit on the front porch". The passive voice of "be made to" in this sentence is the demonstration of Joe's idea that Janie should be mastered and arranged. In the short and happy days before eloping to Eatonville with Joe, she was attracted not only by the vision of unknown life, but also by Joe's material promises to her. Joe told her to let him worry about everything, and that if Janie followed him, she would have a good life. With a good financial life and social position, not only did he give Janie a house with two stories, the fine spitting pot and the respect of everyone, he also gave Janie a high chair, a head-rag and a silenced voice. Experienced years of depressed life, Janie finally realized that she got nothing form Jody that money could buy, and she was giving away what she didn't value. After Joe's death, Janie tore off her scarf, opened the window, and called out to everyone that her husband was dead. And the second half of her life, from a "silent object" to a "subject"'with her own voice began[14]. In Janie's first two marriages, her conflict with herself is that she expects equal status in marriage but at the same time she accepts material support from men. Without a sense of independence, she was shaped into a woman under the influence of social rules[15] and compromised from the years of slavery and sexual exploitation of ancestral women [16]. When the whole community and her grandmother told her that material was more important than love, it was difficult for Janie, as an individual, not to be affected. After Joe's death, Janie dug into her heart and admits that she resented her Nanny for distorting her values in the name of love. After these two marriages full of material dependence, Jenny finally recognized her needs. She did not expect marriage and men to bring any good changes to her life, just enjoying the free days, until she met her Tea Cake. In the third conflict with herself-the conflict between the attraction of her advantageous economic position to the opposite gender and her desire for true love. It turned out that Tea Cake was not attracted by her wealth, and Janie went from worrying that he didn't seem to have any money, maybe he's hanging around her, trying to please her and taking all her money to telling others firmly that he didn't spend all her money, didn't leave her for young girls and gave her all the comfort in the world. Compared with the example of Annie Tyler, another women character who was cheated out of her money by a young man, Janie's luck as a black woman was not common, which was like the existence of the Everglades at that time, like an unrealistic dream, and also indicated that Janie's sweet love and economic status actually had another profound meaning. Hurston once explained in a footnote the meaning of the phrase "You're not white": Don't be too ambitious, you're only black, so you shouldn't have so much[18]. Through the arrangement of Janies' third marriage, Hurston rebelled against the idea of white supremacy, and took her lucky third marriage as an example to show black women that they were no different from other races, that they could have many possibilities, and that they could pursue the diversity of their life values.

The economic element is hidden in narrative process, breaking the material dependence in Janie's consciousness through the conflicts between Jenny and herself. Hurston shows great concerns for the realization of women's self-worth in her works, which is reflected in Janie's conflict with herself and her growth in the process of pursuing self-independence, and finally her ideology changes and she moves towards freedom and independence. However, from Janie's inheritance of her deceased husband's property, she could not completely get rid of her dependence on the means of production created by men, therefore, Janie' growth was incomplete, and her spiritual independence was still based on the material basis provided by men in a sense. In the third marriage, Jenny benefited from her inheritance of her late husband's property and her third husband was not greedy for money. These two advantages weakened her conflict with herself, but the problem was still not completely solved. In the society at that time, whether black women 
could obtain real spiritual independence without relying on the economic wealth created by men or not is the problem that Hurston left behind in this work, and perhaps it is also her confusion on the road of pursuing the realization of self-worth of black women.

\section{Economic Elements Shaping Characters}

The economic elements in Their Eyes Were Watching God not only play a role in the background of the story, the promotion of the plot and the creation of conflicts, but also in the shaping of the characters. Whether it was Logan who expected Jenny to bow down because he owned sixty acres of land, Joe who wanted to control Jenny because he had become mayor and owned a store, or her Nanny who married Jenny for Logan's economic strength, Janie who has become cautious of wealth because of her inheritance from Joe, and the people who care too much about Janie's money in the story are all affected by the economic elements to some extent. Economic self-confidence magnifies the strong and male hegemonic ideas in Logan and Joe's personality, making them have a desire to control and oppress Janie; the improvement of economic status has changed Janie's initial attitude of money-careless, making her suspicious of her suitors, including Tea Cake; the neighbors' comments and concerns about Janie being almost everywhere reflects the strong impact of economy on people.

Among all the characters, Tea Cake, with the migratory spirit of the African American community, is a person who is not affected and bound by the economy, takes Janie to find a sense of belonging in the Everglades and becomes the backbone and savior of the African American community [19]. When he first met Janie, he explained his attitude to money-- if he wants to take a train, he will take it, whether he has money or not; he does not want Janie's funds; he does not even have the idea of hoarding capital--he accidentally got two hundred from Jenny and almost spent all the money to hold an incredible party because he wanted to experience what it's like to be a rich man. From what mentioned above, the image of Tea Cake and the image of the Everglades reach to a high degree of similarity, the coincidence lies in the his indifferent attitude to money and the unrealistic economic structure of the Everglades; The fact that he led Janie to the Everglades, that he became the spiritual leader of the people of the Everglades and that Janie left the Everglades after his death further illustrate that the image of him is actually a part of the Everglades, an embodiment of a third space which is far away from the real economy, brutal but inclusive, poor but vibrant.

The character of Tea Cake is different from the two flat characters of Logan and Joe, because he has more than one dimension, thus showing a round character [20]. The roundness of Tea Cake lies in the lack of economic desire in him, which not only plays a positive role, but also highlights the defects of the character. What Logan and Joe show in their marriage with Janie is a kind of conditional male hegemony, with the condition being that the economic status of men is higher than that of women, and lead to the oppression of women, while Tea Cake, whose economic status is lower than that of Jenny, has an unconditional male hegemony for Jenny. Viewing the novel from its structure, Chapter 14 is the watershed of the whole book. In the following chapters, besides a discussion about money and color between Mrs. Turner, who blindly worship the color of white people, and Janie, economic elements are not involved in all the events: days of working in the Everglades; everyone taking shelter from the storm; the dessert getting rabies; Janie shooting the crazy Tea Cake to protect herself. From another point of view, it just reflects the narrative function of economic elements in an indirect way, which creates a character like Tea Cake who has little connection with the real economy, separates reality with his existence and that of the Everglades, and lets him dispel Janie's worries to her spouse as a propertied person. Hurston does not shy away from the taboo of writing about domestic violence in the black race when she is portraying the character of Tea Cake. His complexity lies in that he treats Janie as an equal person most of the time and leads her to a more free life, but he still has patriarchal ideas and desires to control her, such as slapping her in order to show his position as the leader of the family, because in his opinion if he can hit her, he will prove that she belongs to him. Through Tea Cake, a character in an economically disadvantaged position, Hurston reveals the unconditional male hegemony imposing on black women in marriage that they suffer from men.

Economic elements in this novel participate in the characterization of the characters by depicting the economic consciousness and growth of Janie, the conditional male hegemony of Logan and Joe as well as the people who keep a close eye on Janie's property; it also depicts a character who is not affected by money and behaves his own way--Tea Cake, a character who is in an economically disadvantaged position in his marriage with Janie but still able to oppress her with unconditional male hegemony. Through these roles shaped by economic elements, Hurston shows the influence of economic status on men and women, and exposes the male hegemony in the society and marriage at that time: No matter how understanding a husband Tea Cake is, as long as they still live in a male-dominated society, Janie will not be able to fully develop herself through marriage.

\section{Conclusion}

The narrative function of the economic elements in Their Eyes Were Watching God is mainly manifested in three aspects: participating in the construction of the social background, promoting the development of the plot and the conflict of the characters, and shaping the image of the characters. Through the construction of West Florida and Eatonville based on the realistic economic structure and the Everglades based on the extremely unrealistic economic structure, Hurston implies that a society in which men and women have equal economic status is the basis for women to pursue equal human rights; through 
the economic elements in promoting the development of the plot and the conflict of characters, Hurston expresses her concerns for the realization of women's self-worth and her reflection on how women get rid of material dependence; through the characterization of economic elements, Hurston reveals the conditional hegemony and unconditional hegemony imposed by men on women, and expresses her lament for women living in a maledominated society.

Through the narrative function of economic elements in the novel, confusion and powerlessness beneath the surface story of women's growth can be seen, however, whether it is Hurston's ambiguous expression due to the limitation of historical understanding or the author's predicament and confusion about the value goal of women's survival [22], there is no denying that she did make the first real black female voice [23]. In fact, the narrative of Their Eyes Were Watching God does not end with the novel, because Hurston always keeps some secrets of life [24], therefore she also leaves some room for imagination in the novel. Narration has the magical power to stimulate imagination and move people, and the power of narrative lies in communication [25]. At the end of the novel, when Pheoby, as a listener, is ready to leave, Janie tells her that she can spread Janie's life story. Awakening and growth of women cannot be achieved overnight, Janie's incomplete story of personal growth may inspire other women's awakening in the process of dissemination, as Pheoby said after listening to the story: 'Ah done growed ten feet higher from jus' listenin' tuh you, Janie. Ah ain't satisfied wid mahself no mo"'. Janie and Hurston are actually encouraging women to "jump at the sun" in their own way through the special narrative form with the assistance of economic elements.

\section{References:}

1. Gates,H.L. (1997). The Norton Anthology of African American Literature. W.W. Norton \& Company, New York. p.522.

2. Cheng, X.L. (2007). A Study on Zora Heale Hurston. Shanghai Foreign Language Education Press, Shanghai. P. 110.

3. Lv, Q.(2017). An Analysis of Their Eyes Were Watching God in the View of Bourdieu's Generating Structural Theory of Capital. English and American Literary Studies, 26:224-234.

4. Hu,X.J.(2014). The Economic Status of African American Women: An Economic Interpretation of Their Eyes Were Watching God. Forward Position, $355 \& 356: 187-189$ 。

5. Manzella, A.(2018). In Migrating Fictions: Gender, Race, and Citizenship in U.S. Internal Displacements.Columbus: Ohio State University Press, Ohio. pp 28-66.

6. Haddox,T. (2001). The Logic of Expenditure in "Their Eyes Were Watching God". Mosaic: An Interdisciplinary Critical Journal,34:19-34.
7. Hurston,Z.N.(2013).Their Eyes Were Watching God. Harper Perennial Modern Classics. New York. P.29.

8. Zhou, L.P.(2013). An Analysis of the Employment Situation of African American Women during the Great Depression. History Research and Teaching, 2013(03):11.

9. Ware, S. (1982). Holding Their Own: American Women in the 1930s. Boston G.K.Hall \& Co., Boston.p.13.

10. Wang, J.X. (1989). In the Shadow of Richard Wright- Zora Neale Hurston and Ann Patery, Two Black American Women Writers in the 1930s and 1940s. Foreign Literature.1989(01):77.

11. Beauvoir, S.(2009). The Second Sex. Xiyuan Publishing House, Beijing. P.21.

12. Tan, R. J.(1991). On Marriage and Economic Relations. Economic Review. 1991(02):68.

13. Shen, D.(2016). Conflicts behind Plot Conflicts: Double Narrative Movement in Kafka's The Verdict. Foreign Literature Review.2016(01):98.

14. Cheng, X.L.(2003). On Feminist Consciousness in Their Eyes Were Watching God. Journal of Sichuan University ( Social Science Edition).127: 78.

15. Moi, T.(1985).Sexual/Textual Politics: Feminist Literary Theory. Methuen. London. P.92.

16. Bell, B.(1987).The Afro-American Novel and Its Tradition.University of Massachusetts Press.p. 126.

17. Hurston,Z.N..(1942).Dust Tracks on a Road: An Autobiography.University of Illinois Press.Urbana. p.38.

18. Liu.Y.(2019). Migration or anti-migration? African American Population Movement in the Works of Zora Neale Hurston. Journal of Literature in English. 2019(01): 20.

19. Forster, E.M.(2016). Aspects of the Novel, Translated by Feng. T.Z. Shanghai Translation Publishing House. Shanghai. P.61.

20. Miles,D.(2000).Women, Violence, and Testimony in the works of Zora Neale Hurston.Bell\&Howell Information and Learning Company. P.2.

21. Jiao,X.T.(2014).Hurston's Nonplus: An Analysis of the Heroine in Their Eyes Were Watching God.Foreign Language and Literature. 30:7.

22. Gates,H.L.Jr..Appiah, K.A.,ed.(1993).Zora Neale Hurston: Critical Perspectives Past and Present.Amistad. New York.p.76.

23. Hemenway,R.E.(1977). Zora Neale Hurston: A Literary Biography. Urbana and Chicago:University of Illinois Press.p.13.

24. Yu,J. (2020). The Power of Narration. chinatimes.net.cn. https://www.chinatimes.net.cn/article/96722.html. 